\title{
Early and mid-term results of autograft rescue by Ross reversal: A one-valve disease need not become a two-valve disease
}

\author{
Syed T. Hussain, MD, ${ }^{a}$ David S. Majdalany, MD, ${ }^{\mathrm{b}}$ Aaron Dunn, BA, ${ }^{\mathrm{c}}$ Robert D. Stewart, MD, ${ }^{\mathrm{a}}$ \\ Hani K. Najm, MD, ${ }^{a}$ Lars G. Svensson, MD, PhD, ${ }^{a}$ Penny L. Houghtaling, MS, ${ }^{\mathrm{d}}$ \\ Eugene H. Blackstone, MD, ${ }^{\mathrm{a}, \mathrm{d}}$ and Gösta B. Pettersson, MD, PhD ${ }^{\mathrm{a}}$
}

\section{ABSTRACT}

Objectives: Risk of reoperation and loss of a second native valve are major drawbacks of the Ross operation. Rather than discarding the failed autograft, it can be placed back into the native pulmonary position by "Ross reversal." We review our early and mid-term results with this operation.

Methods: From 2006 to 2017, 39 patients underwent reoperation for autograft dysfunction. The autograft was successfully rescued in 35 patients: by Ross reversal in 30, David procedure in 4, and autograft repair in 1. Medical records were reviewed for patient characteristics (mean age was $46 \pm 13$ years, range 18-67 years, and 23 were male), previous operations, indications for reoperation, hospital outcomes, and echocardiographic findings for the 30 patients undergoing successful Ross reversal. Follow-up was $4.1 \pm 3.5$ years (range 7 months-11 years).

Results: Median interval between the original Ross procedure and Ross reversal was 12 years (range 5-19 years). Eight patients also had absolute indications for replacement of the pulmonary allograft. There was no operative mortality. One patient required reoperation for bleeding. Another had an abdominal aorta injury from use of an endoballoon clamp. There was no other major postoperative morbidity, and median postoperative hospital stay was 7.2 days (range 441 days). No patient required reoperation during follow-up. Twenty-four patients had acceptable pulmonary valve function, and 6 had clinically well-tolerated moderate or severe pulmonary regurgitation.

Conclusions: Ross reversal can be performed with low morbidity and acceptable pulmonary valve function, reducing patient risk of losing 2 native valves when the autograft fails in the aortic position. (J Thorac Cardiovasc Surg 2018;155:562-72)

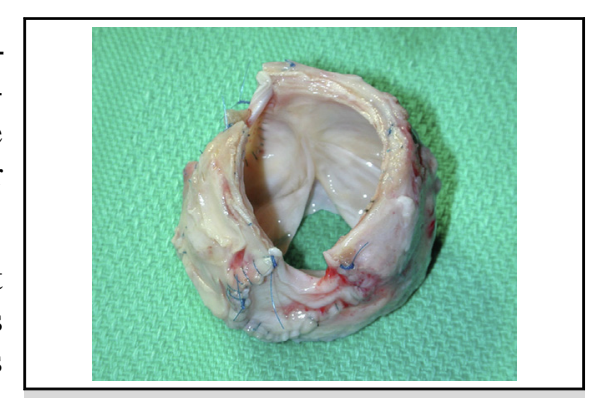

Excised and refashioned autograft ready for Ross reversal to its native pulmonic position.

\section{Central Message}

Ross reversal rescues the native valve in patients with autograft dysfunction who require reoperation and provides acceptable pulmonary valve function and freedom from reoperation.

\section{Perspective}

Root replacement for a failed autograft leaves the patient undergoing reoperation after a Ross procedure with an allograft in the pulmonic position, subject to further deterioration requiring future intervention. Reuse of the dysfunctional autograft by Ross reversal is feasible, safe, and reproducible and provides acceptable pulmonary valve function, reducing the risk of the patient losing 2 native valves when the autograft fails in the aortic position.

See Editorial Commentary page 573.

See Editorial page 537.
Survival after the Ross procedure is similar to that of the general population, and the procedure offers numerous advantages over other treatment options for aortic valve

From the Departments of ${ }^{\mathrm{a}}$ Thoracic and Cardiovascular Surgery and ${ }^{\mathrm{b}} \mathrm{Cardiovascular}$ Medicine, Heart and Vascular Institute, Cleveland Clinic; ${ }^{\mathrm{C}}$ Cleveland Clinic Lerner College of Medicine; and ${ }^{\mathrm{d}}$ Department of Quantitative Health Sciences, Research Institute, Cleveland Clinic, Cleveland, Ohio.

This study was funded in part by the Gus P. Karos Registry Fund, the David Whitmire Hearst Jr Foundation, the Slosburg Family Charitable Trust, James and Sharon Kennedy, Stephen and Saundra Spencer, Martin Nielsen, the Drs Sidney and Becca Fleischer Heart and Vascular Education Chair, and the Peter and Elizabeth C. Tower and Family Endowed Chair in Cardiothoracic Research. disease, including superior quality of life, unrestricted daily activities, freedom from lifelong anticoagulation, and normal aortic valve hemodynamics. ${ }^{1-10}$ Patients who

Read at the 97th Annual Meeting of The American Association for Thoracic Surgery, Boston, Massachusetts, April 29-May 3, 2017.

Received for publication May 10, 2017; revisions received Aug 1, 2017; accepted for publication Sept 1, 2017.

Address for reprints: Gösta B. Pettersson, MD, PhD, Department of Thoracic and Cardiovascular Surgery, Cleveland Clinic, 9500 Euclid Ave/Desk J4-1, Cleveland, OH 44195 (E-mail: petterg@ccf.org).

0022-5223/\$36.00

Copyright (c) 2017 by The American Association for Thoracic Surgery

https://doi.org/10.1016/j.jtcvs.2017.09.134 


\section{Abbreviation and Acronym}

$\mathrm{TPVR}=$ transcatheter pulmonary valve replacement

Scanning this $\mathrm{QR}$ code will take you to a supplemental video. To view the AATS Annual Meeting Webcast, see the URL next to the webcast thumbnail.

choose a Ross operation are generally young and expect that the procedure will provide a permanent, normalfunctioning aortic valve and that degeneration of the pulmonary allograft will be inconsequential. However, technical complexity of the procedure and need for reoperation or reintervention on either the autograft, the allograft, or both, remain the primary concerns. ${ }^{1-17}$ Need for reoperation on the autograft presents important challenges: first, patient disappointment that reoperation is necessary, and second, the risk of losing a second native valve-the failed pulmonary autograft-potentially creating 2-valve disease in patients who only had aortic valve disease.

Rather than discard the failed autograft, we have placed it back into the native pulmonary position, a procedure known as "Ross reversal." Here we report our early and mid-term results with this operation.

\section{PATIENTS AND METHODS \\ Patients}

From 2006 to 2017, 39 consecutive patients underwent reoperation for autograft dysfunction at Cleveland Clinic by a single surgeon (G.B.P.). All but 1 had their original Ross operation performed elsewhere. The autograft was successfully rescued in 35 patients: by Ross reversal in 30, David procedure in 4 , and valve repair in 1 . The autograft could not be rescued in 4 additional patients $(10 \%), 1$ each due to previous subcoronary autograft implantation, failed autograft valve repair, attempted David procedure, and poor autograft quality. The 30 patients who underwent Ross reversal are the subject of this study.

\section{Data}

Medical records were reviewed for patient characteristics, previous operations, indications for operation, hospital outcomes, and echocardiographic findings. Mean age was $46 \pm 13$ years (range 18-67 years), and $23(76 \%)$ were men (Table 1). Twenty-one procedures were first-time reoperations, 6 second-time, 1 third-time, and 2 fourth-time. Twelve concomitant procedures were performed, including hemiarch replacement in 5 patients (Tables 2 and 3). All patients undergoing Ross reversal had had the autografts implanted as complete roots with or without anulus and sinutubular junction support.

The Cleveland Clinic Institutional Review Board approved data extracted from all registries and medical records for use in research, with patient consent waived (IRB 16-1346).
TABLE 1. Preoperative patient characteristics $(n=30)$

\begin{tabular}{lc}
\hline \multicolumn{1}{c}{ Characteristics } & No. $(\%)$ \\
\hline Demographics & \\
Age, y, mean \pm SD & $46 \pm 13^{*}$ \\
Female & $7(23)$ \\
Comorbidities & \\
NYHA class III or IV & $9(30)$ \\
Hypertension & $17(57)$ \\
Atrial fibrillation & $5(17)$ \\
Coronary artery disease & $1(3.3)$ \\
Preoperative renal dialysis & $1(3.3)$ \\
Chronic obstructive pulmonary disease & $1(3.3)$ \\
Diabetes mellitus & $0(0)$ \\
Peripheral arterial disease & $3(10)$ \\
Previous cardiac operation & \\
1 & $21(70)$ \\
2 & $6(20)$ \\
3 & $1(3.3)$ \\
4 & $2(6.7)$ \\
\hline
\end{tabular}

$S D$, Standard deviation; NYHA, New York Heart Association. *Range 18-67 years.

\section{Surgical Technique}

As described by us previously, ${ }^{18,19}$ the technique of Ross reversal is as follows (Figure 1 and Video 1). All patients undergo intraoperative transesophageal echocardiography. After resternotomy, the right side of the heart and the aorta are mobilized. Aortic and bicaval cannulation are performed and cardiopulmonary bypass instituted. Myocardial protection is by induction with antegrade and retrograde cold blood cardioplegia, followed by retrograde cardioplegia delivered every 15 to 20 minutes, and warm terminal cardioplegia. To ensure cardioplegia delivery to both ventricles, direct coronary sinus cannulation through a purse-string suture is used for retrograde cardioplegia.

The root is dissected out circumferentially down to the anulus, exactly as for a David reimplantation procedure. Coronary buttons are excised and mobilized. If at this stage the valve cusps are good and symmetrical enough to allow a David procedure, the root is ready for reimplantation. If Ross reversal is decided upon, the fibrous connection between the autograft and the left ventricular muscle (usually a 5- to 10-mm-wide fibrous skirt) is cut in the middle, allowing the autograft a 3- to 4-mm rim of tissue for its reimplantation on the right side while leaving a good-quality aortic anulus for implantation of a new aortic valve (of any choice) without compromising the left ventricular outflow tract or the conduction system.

The harvested autograft is inspected and refashioned with reconstructions that include cusp manipulations, downsizing, and filling in of defects with excised excess aortic or autograft tissue or untreated autologous pericardium (Figure 1, B). The pulmonary allograft (or other right ventricular outflow tract conduit) is peeled out, leaving minimal allograft, foreign material, and scar tissue behind.

The aortic root is replaced with either a composite graft containing a mechanical or bioprosthetic valve or an allograft, implanted in standard fashion. Coronary buttons are reimplanted anatomically. The refashioned pulmonary autograft is reimplanted into the right ventricular outflow tract, in the best orientation according to size and shape, using continuous polypropylene suture for both distal and proximal anastomoses (Figure 1, $C$ and $D$ ). Finally, the aortic root is sewn to the distal ascending aorta or distal aortic graft.

Variations on the procedure included the following. In 1 patient, axillary cannulation was used because of the high risk of re-entry injury (patient $\# 29$, Table 2). Six patients required a brief period of hypothermic circulatory arrest for hemiarch replacement. In 1 patient with a dilated autograft in direct contact with the sternum, the technique used for sternal re-entry resulted in serious complications, and this case will be described separately. The autograft anulus suture line had been supported with felt in some 
TABLE 2. Indications for surgery and surgical details of patients undergoing Ross reversal

\begin{tabular}{|c|c|c|c|c|c|c|c|}
\hline \multirow[b]{2}{*}{$\begin{array}{l}\text { Patient } \\
\text { No. }\end{array}$} & \multirow[b]{2}{*}{$\begin{array}{c}\text { Reop } \\
\text { no. }\end{array}$} & \multirow[b]{2}{*}{$\begin{array}{l}\text { Years after } \\
\text { initial Ross }\end{array}$} & \multicolumn{2}{|c|}{ Indication for reoperation } & \multirow[b]{2}{*}{$\begin{array}{c}\text { Aortic root } \\
\text { procedure }\end{array}$} & \multirow[b]{2}{*}{$\begin{array}{l}\text { Additional } \\
\text { procedures }\end{array}$} & \multirow[b]{2}{*}{$\begin{array}{c}\text { Last follow-up } \\
\text { echo, gradient in } \\
\text { mm Hg, peak/mean }\end{array}$} \\
\hline & & & $\begin{array}{c}\text { Aortic valve } \\
\text { (autograft) } \\
\text { related } \\
\end{array}$ & $\begin{array}{c}\text { Pulmonary } \\
\text { valve related } *\end{array}$ & & & \\
\hline 1 & 1 & 11 & $\begin{array}{l}\text { Root aneurysm, } \\
2-3+\mathrm{AR}\end{array}$ & $\begin{array}{l}\text { Severe PS (previously } \\
\text { stented)* }\end{array}$ & $\begin{array}{l}\text { Composite mechanical } \\
\text { root }\end{array}$ & $\begin{array}{l}\text { Hemiarch } \\
\text { replacement }\end{array}$ & $1+\mathrm{PR}, \Delta 10 / 5$ \\
\hline 2 & 1 & 10 & $\begin{array}{l}\text { Root, asc., and } \\
\text { proximal arch } \\
\text { aneurysm }\end{array}$ & None & $\begin{array}{l}\text { Composite mechanical } \\
\text { root }\end{array}$ & $\begin{array}{l}\text { Hemiarch } \\
\text { replacement, } \\
\text { epicardial lead } \\
\text { placement }\end{array}$ & $2+\mathrm{PR}, \Delta 3 / 2$ \\
\hline 3 & 1 & 6 & $4+\mathrm{AR}, \operatorname{root} 5 \mathrm{~cm}$ & Moderate PS & $\begin{array}{l}\text { Allograft root } \\
\text { replacement }\end{array}$ & & Trivial PR, $\Delta 10 / 6$ \\
\hline 4 & 2 & 8 & $\begin{array}{l}\text { 3-4+ AR, significant } \\
\text { subaortic dynamic } \\
\text { LVOT gradient }\end{array}$ & None & $\begin{array}{l}\text { Composite mechanical } \\
\text { root }\end{array}$ & $\begin{array}{l}\text { Myectomy, mitral } \\
\text { valve replacement, } \\
\text { tricuspid valve } \\
\text { repair }\end{array}$ & Trivial PR, $\Delta 18 / 7$ \\
\hline 5 & 1 & 10 & $\begin{array}{r}4+\mathrm{AR}, \text { dilated } \\
\operatorname{root}(4.5 \mathrm{~cm})\end{array}$ & $\begin{array}{l}2-3+\text { PR, moderate } \\
\quad \text { PS }\end{array}$ & $\begin{array}{l}\text { Allograft root } \\
\text { replacement }\end{array}$ & $\begin{array}{l}\text { Hemiarch } \\
\text { replacement, } \\
\text { CABG }\end{array}$ & $2-3+\mathrm{PR}, \Delta 14 / 7$ \\
\hline 6 & 1 & 5 & $\begin{array}{r}4+\mathrm{AR}, \text { dilated } \\
\operatorname{root}(4.5 \mathrm{~cm})\end{array}$ & Mild PS & $\begin{array}{l}\text { Allograft root } \\
\text { replacement }\end{array}$ & & Mild PR, peak $\Delta 15$ \\
\hline 7 & 1 & 13 & $\begin{array}{c}4+\mathrm{AR} \text {, root } \\
\text { aneurysm }\end{array}$ & $\begin{array}{l}2+\text { PR, moderate } \\
\text { PS }\end{array}$ & $\begin{array}{l}\text { Composite mechanical } \\
\text { root }\end{array}$ & & Trivial PR, $\Delta 6 / 3$ \\
\hline 8 & 1 & 10 & $4+\mathrm{AR}$ & None & $\begin{array}{l}\text { Composite mechanical } \\
\text { root }\end{array}$ & & Mild PR, peak $\Delta 13$ \\
\hline 9 & 1 & 11 & $4+\mathrm{AR}$ & $\begin{array}{l}\text { Moderate PS, calcified } \\
\text { allograft }\end{array}$ & Allograft root replacement & & $2+\mathrm{PR}$, peak $\Delta 8$ \\
\hline $10_{\ddagger}^{\ddagger}$ & 3 & 12 & $\begin{array}{c}4+\mathrm{AR}, \text { root } \\
\text { aneurysm }\end{array}$ & $\begin{array}{l}\text { Previous allograft } \\
\text { replaced with } \\
\text { freestyle valve }\end{array}$ & $\begin{array}{l}\text { Composite mechanical } \\
\text { root }\end{array}$ & & $2+\mathrm{PR}, \Delta 9 / 4$ \\
\hline 11 & 2 & 15 & $\begin{array}{l}1-2+\mathrm{AR}, \text { root, } \\
\text { and asc. aorta } \\
\text { aneurysm }\end{array}$ & $\begin{array}{l}\text { Severe PR (previously } \\
\text { replaced allograft)* }\end{array}$ & Bioroot replacement & $\begin{array}{l}\text { Hemiarch } \\
\text { replacement }\end{array}$ & Trivial PR, $\Delta 7 / 3$ \\
\hline 12 & 1 & 18 & $\begin{array}{l}4+\mathrm{AR}, \text { large root } \\
\text { and asc. aneurysm }\end{array}$ & Severe PS* & $\begin{array}{l}\text { Composite mechanical } \\
\text { root }\end{array}$ & $\begin{array}{l}\text { Hemiarch } \\
\text { replacement, } \\
\text { tricuspid valve } \\
\text { repair }\end{array}$ & $1-2+P R$ \\
\hline 13 & 2 & 13 & $\begin{array}{l}2-3+\mathrm{AR}, \text { root } \\
\text { aneurysm }\end{array}$ & $\begin{array}{l}\text { Mild-moderate PS, } \\
1-2+\text { PR (previously } \\
\text { replaced allograft) }\end{array}$ & $\begin{array}{l}\text { Composite mechanical } \\
\text { root }\end{array}$ & & Trivial PR, $\Delta 4 / 2$ \\
\hline 14 & 2 & 18 & $\begin{array}{l}\text { 3-4+ AR, root } \\
\text { aneurysm }\end{array}$ & $\begin{array}{l}\text { Severe PS, previously } \\
\text { operated for } \\
\text { severe PS* }\end{array}$ & Bioroot replacement & & No PR, $\Delta$ 20/10 \\
\hline 15 & 1 & 15 & $\begin{array}{c}2+\mathrm{AR}, \text { root } \\
\text { aneurysm }\end{array}$ & Moderate PS, 2+ PR & $\begin{array}{l}\text { Composite mechanical } \\
\text { root }\end{array}$ & & Trivial PR, $\Delta 3 / 2$ \\
\hline 16 & 1 & 10 & $\begin{array}{c}4+\mathrm{AR}, \text { root } \\
\text { aneurysm }\end{array}$ & $4+\mathrm{PR}^{*}$ & $\begin{array}{l}\text { Composite mechanical } \\
\text { root }\end{array}$ & & Trivial PR, $\Delta 9 / 4$ \\
\hline 17 & 1 & 17 & $\begin{array}{c}2+\mathrm{AR}, \text { root } \\
\text { aneurysm }\end{array}$ & Moderate PS, 2+ PR & Bioroot replacement & & $1+\mathrm{PR}, \Delta 22 / 11$ \\
\hline 18 & 1 & 11 & $\begin{array}{c}3+\mathrm{AR}, \text { root } \\
\text { aneurysm }\end{array}$ & Moderate PS, 1-2+ PR & Bioroot replacement & & Trivial PR \\
\hline
\end{tabular}


TABLE 2. Continued

\begin{tabular}{|c|c|c|c|c|c|c|c|}
\hline \multirow[b]{2}{*}{$\begin{array}{l}\text { Patient } \\
\text { No. }\end{array}$} & \multirow[b]{2}{*}{$\begin{array}{c}\text { Reop } \\
\text { no. }\end{array}$} & \multirow[b]{2}{*}{$\begin{array}{l}\text { Years after } \\
\text { initial Ross }\end{array}$} & \multicolumn{2}{|c|}{ Indication for reoperation } & \multirow[b]{2}{*}{$\begin{array}{l}\text { Aortic root } \\
\text { procedure }\end{array}$} & \multirow[b]{2}{*}{$\begin{array}{l}\text { Additional } \\
\text { procedures }\end{array}$} & \multirow[b]{2}{*}{$\begin{array}{c}\text { Last follow-up } \\
\text { echo, gradient in } \\
\text { mm Hg, peak/mean }\end{array}$} \\
\hline & & & $\begin{array}{c}\text { Aortic valve } \\
\text { (autograft) } \\
\text { related }\end{array}$ & $\begin{array}{c}\text { Pulmonary } \\
\text { valve related } *\end{array}$ & & & \\
\hline 19 & 1 & 9 & $\begin{array}{c}3+\mathrm{AR}, \text { root } \\
\text { aneurysm }\end{array}$ & Moderate PS, 1-2+ PR & $\begin{array}{l}\text { Composite mechanical } \\
\text { root }\end{array}$ & & $1+\mathrm{PR}, \Delta 8 / 4$ \\
\hline $20 \S$ & 4 & 18 & $\begin{array}{c}4+\mathrm{AR}, \text { root } \\
\text { dilatation }\end{array}$ & $\begin{array}{l}\text { Moderate PS, calcified } \\
\text { allograft }\end{array}$ & $\begin{array}{l}\text { Composite mechanical } \\
\text { root }\end{array}$ & & No PR, $\Delta 18 / 11$ \\
\hline 21 & 1 & 5 & $4+\mathrm{AR}$ & Mild PS & Bioroot replacement & & Mild PR, $\Delta 34 / 16$ \\
\hline 22 & 1 & 12 & $\begin{array}{l}\text { 3-4+ AR, root } \\
\text { aneurysm }\end{array}$ & None & $\begin{array}{l}\text { Composite mechanical } \\
\text { root }\end{array}$ & & Trivial PR, $\Delta 21 / 11$ \\
\hline $23 \|$ & 4 & 18 & $\begin{array}{l}2-3+\mathrm{AR}, \text { root } \\
\text { aneurysm }\end{array}$ & $\begin{array}{l}\text { Three previous } \\
\text { replacements of } \\
\text { pulmonary valve, } \\
\text { currently has } \\
\text { bioprosthetic } \\
\text { valve conduit }\end{array}$ & $\begin{array}{l}\text { Composite mechanical } \\
\text { root }\end{array}$ & & No PR, $\Delta 19 / 10$ \\
\hline 24 & 1 & 19 & $\begin{array}{l}\text { 2-3+ AR, } \\
\text { subvalvular } \\
\text { fibrosis/constriction }\end{array}$ & Severe PS* & $\begin{array}{l}\text { Composite mechanical } \\
\text { root }\end{array}$ & & Trivial PR, peak $\Delta 22$ \\
\hline 25 & 1 & 20 & $\begin{array}{c}2+\mathrm{AR}, \text { root } \\
\text { aneurysm } \\
\text { (previously } \\
\text { revised Ross) }\end{array}$ & Severe PS* & $\begin{array}{l}\text { Composite mechanical } \\
\text { root }\end{array}$ & & No PR, peak $\Delta 19$ \\
\hline 26 & 2 & 17 & $\begin{array}{c}4+\mathrm{AR}, \text { root } \\
\text { aneurysm }\end{array}$ & None & $\begin{array}{l}\text { Composite mechanical } \\
\text { root }\end{array}$ & & Trivial PR \\
\hline 27 & 1 & 15 & $\begin{array}{l}2-3+\mathrm{AR}, \text { root } \\
\text { aneurysm }\end{array}$ & None & $\begin{array}{l}\text { Composite mechanical } \\
\text { root }\end{array}$ & & No PR, $\Delta 4 / 2$ \\
\hline 28 & 1 & 6 & $\begin{array}{c}2+\mathrm{AR}, \text { root } \\
\text { aneurysm }\end{array}$ & None & $\begin{array}{l}\text { Composite mechanical } \\
\text { root }\end{array}$ & & $2-3+\mathrm{PR}, \Delta 24 / 13$ \\
\hline 29 & 2 & 17 & $\begin{array}{c}4+\mathrm{AR}, \text { root } \\
\text { aneurysm }\end{array}$ & Mild PS & $\begin{array}{l}\text { Composite mechanical } \\
\text { root }\end{array}$ & $\begin{array}{l}\text { Repair of abdominal } \\
\text { aortic injury }\end{array}$ & $2+\mathrm{PR}, \Delta 34 / 14$ \\
\hline 30 & 1 & 15 & $\begin{array}{r}3+\mathrm{AR}, \text { root } \\
\text { aneurysm }\end{array}$ & Severe PS, $1-2+\mathrm{PR}^{*}$ & $\begin{array}{l}\text { Composite mechanical } \\
\text { root }\end{array}$ & $\begin{array}{l}\text { Tricuspid valve } \\
\text { repair }\end{array}$ & Trivial PR, peak $\Delta 6$ \\
\hline
\end{tabular}

$1+=$ mild, $2+=$ moderate, $3+=$ moderate to severe, and $4+=$ severe regurgitation. Reop, Reoperation; $A R$, autograft regurgitation; $P S$, pulmonary stenosis; $P R$, pulmonary regurgitation; asc., ascending; $L V O T$, left ventricular outflow tract; $C A B G$, coronary artery bypass grafting. *Secondary indication unless otherwise noted. $\dagger$ Missing gradients because of incomplete interrogation of pulmonary valve due to technical reasons. †ेPrevious aortic valve replacement, Ross procedure, and subsequent replacement of allograft with a porcine root. §Two previous aortic valve repairs, then aortic valve replacement, and subsequent Ross procedure. ||Ross procedure and 3 subsequent reoperations on the pulmonary valve.

patients, and in a few this had caused important calcification; however, in all cases this could be debrided without injuring the autograft valve, and in no case did it prevent reusing the autograft.

\section{Follow-up}

Patients were followed systematically by the anniversary method using an institutional research board-approved questionnaire or telephone script, with patient consent at each follow-up. This was supplemented by crosssectional follow-up. Mean follow-up was $4.1 \pm 3.5$ years (range 7 months- 11 years); $75 \%$ had more than 1 year and $25 \%$ more than 6.5 years of follow-up data. Echocardiography reports (either done at our center during follow-up or provided by local cardiologists) were compiled. Echo follow-up ranged from 5 days to 10.5 years, median 2.5 years $(25$ th, 75 th percentiles, 0.20, 5.6).

\section{Data Analysis}

All analyses were performed with SAS statistical software (SAS version 9.2; SAS Institute, Cary, NC). Continuous variables are summarized by mean \pm standard deviation, and categorical variables are summarized by frequencies and percentages.

\section{RESULTS}

The median interval between the original Ross procedure and Ross reversal was 12 years (range 5-19 years). All patients had autograft dysfunction (Table 2) with regurgitation, with or without root dilatation or aneurysm. Eight patients also had absolute indication and 15 relative 
TABLE 3. Operative details of patients undergoing Ross reversal $(\mathbf{n}=\mathbf{3 0})$

\begin{tabular}{lr}
\multicolumn{1}{c}{ Details } & No. $(\%)$ \\
\hline Concomitant procedures & $12(40)$ \\
Hemiarch replacement & $5(17)$ \\
Tricuspid valve repair & $3(10)$ \\
Coronary artery bypass grafting & $1(3.3)$ \\
Mitral valve replacement & $1(3.3)$ \\
Epicardial lead placement & $1(3.3)$ \\
Myectomy & $1(3.3)$ \\
Operative experience & \\
Cardiopulmonary bypass time, min & $174 \pm 42 *$ \\
Myocardial ischemic time, min & $143 \pm 25 *$ \\
Blood product use $\dagger$ & \\
Red blood cells & $13(43)$ \\
Fresh-frozen plasma & $19(63)$ \\
Platelets & $22(73)$ \\
Cryoprecipitate & $2(6.7)$ \\
Any & $24(80)$ \\
\hline
\end{tabular}

*Mean \pm standard deviation. $\dagger$ Intraoperative and postoperative.

indication for replacement of the pulmonary allograft (Table 2). Seven patients had normally functioning pulmonary allograft valves on echocardiography (Table 2).

There was no in-hospital mortality (Table 4). Median postoperative hospital stay was 7.2 days (range 4-41 days; Table 4). One patient (patient \#23, with 4 previous sternotomies; Table 2) required re-exploration for a large pericardial effusion 3 days after the Ross reversal.

Only 1 patient had a major intraoperative adverse event (patient \#29 in Table 2), which was not related to the Ross reversal procedure per se but to injury of the abdominal aorta from use of an endoballoon clamp. This patient had developed an autograft aneurysm, along with severe aortic regurgitation. The aneurysm was very close to the sternum, and the right coronary artery was immediately behind the sternum. Because of the anticipated high risk of injury during sternal reentry, reoperation was planned with preparedness for reopening on cardiopulmonary bypass and cooling, right axillary cannulation, use of an endoballoon clamp for aortic occlusion, and retrograde coronary sinus cardioplegia delivery for myocardial protection. On bypass with moderate hypothermia and low flow, the sternum was safely reopened, but upon inflating the endoballoon, it embolized to the distal abdominal aorta, resulting in abdominal aortic rupture. While compressing the descending aorta against the spine, abdominal control and aortic repair were possible. Once the abdominal aorta was secured, Ross reversal was completed as planned. The chest and abdomen were left open and subsequently closed on postoperative day 3 . The patient required prolonged ventilation, tracheostomy, and temporary dialysis for renal failure (Table 4) but was eventually discharged from the hospital on postoperative day 41 and recovered well thereafter, returning to work 6 months after the operation.

\section{Follow-up}

All patients were alive at follow-up, and none had required a cardiac-related reoperation. Twenty-four patients $(80 \%)$ were free of pulmonary valve dysfunction by echocardiography, with dysfunction defined by presence of moderate or severe pulmonary regurgitation or peak systolic gradient of $\geq 40 \mathrm{~mm} \mathrm{Hg}$ during follow-up. ${ }^{1,15}$ Highest peak systolic pulmonary gradient was $34 \mathrm{~mm} \mathrm{Hg}$, and only 2 patients had more than moderate pulmonary regurgitation (Table 2). The first patient who underwent the reverse Ross procedure in 2006 had mild pulmonary regurgitation and a peak systolic gradient of $10 \mathrm{~mm} \mathrm{Hg}$ 11 years later. All 6 patients with moderate or greater pulmonary valve regurgitation were without symptoms and are being closely followed by their cardiologists.

\section{DISCUSSION \\ Principal Findings}

Mid-term results show that Ross reversal is a safe operation with low morbidity and good pulmonary valve function in most patients. The only serious adverse intraoperative event was a technical re-entry complication unrelated to the Ross reversal. No patient has required a cardiac reoperation during the follow-up period.

\section{Ross Reversal}

The idea of Ross reversal was conceived and based on our increasing experience not only with autograft and allograft reoperations but with David reimplantation in valve-sparing operations. ${ }^{18,19}$ The basic concepts of the Ross reversal are that (1) an autograft valve in the aortic position, good enough to keep the patient alive and reasonably functional, should be acceptable in the pulmonic position, because pressure and stress on the valve are lower and pulmonary valve function is less critical than aortic valve function; and (2) a live autograft should have better longevity when placed back into the pulmonary position than a pulmonary allograft.

Ross reversal has proven to be predictable and reproducible. It is a major procedure, but technical aspects of autograft dissection can be accomplished reproducibly by any experienced aortic root surgeon familiar with Bentall, allograft, Ross, David, and other advanced aortic root primary and reoperative procedures. Autograft dissection and harvesting for Ross reversal are the same as for a David reimplantation. Removing the allograft and subsequently reimplanting the autograft in the pulmonic position is the easier part of the operation. Reconstructed downsized autografts have provided acceptable valve function in the pulmonic position, and residual regurgitation has been well 


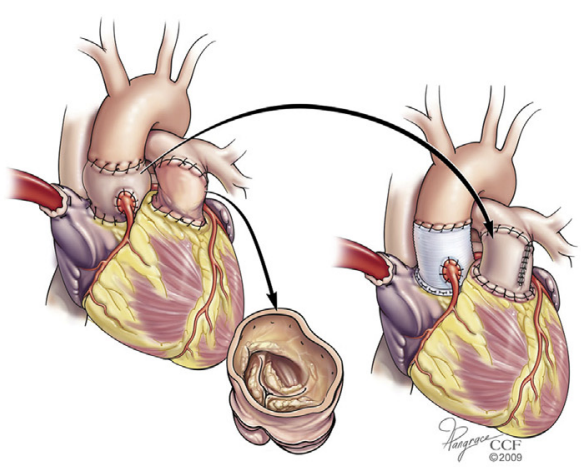

A

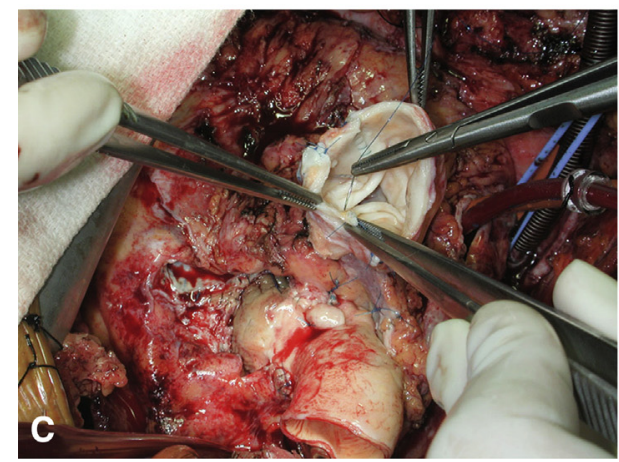

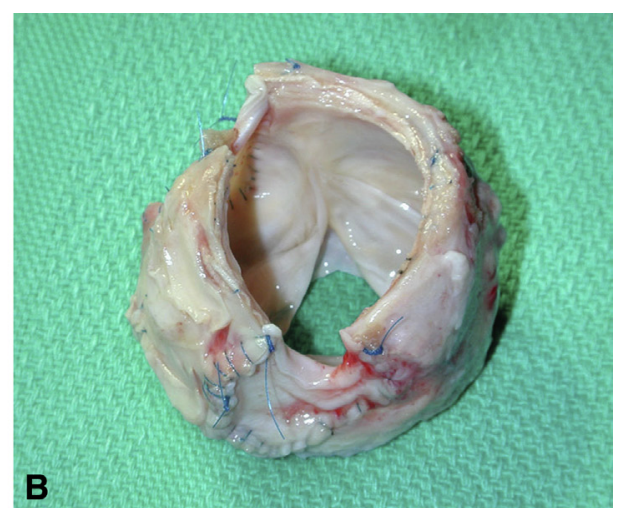
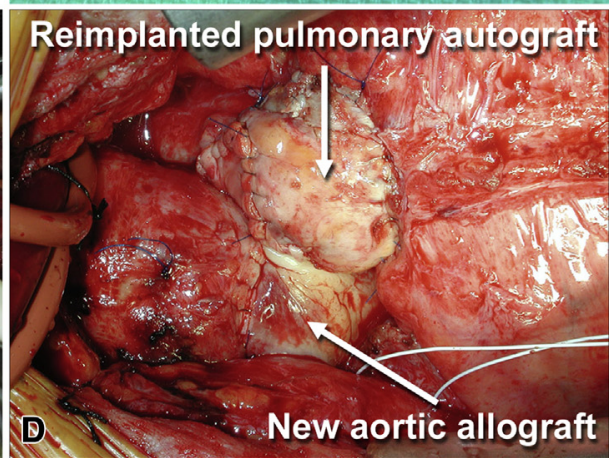

FIGURE 1. Ross reversal procedure. A, Explanted autograft is reimplanted back to the native pulmonary position. B, Explanted autograft refashioned with autologous pericardium. C, Refashioned autograft is reimplanted into the pulmonary position. Aortic root is replaced by an allograft. D, Completed Ross reversal. The autograft has been reimplanted into the native pulmonary position.

tolerated. Function has remained stable, with no patient requiring reoperation.

The final decision on whether to perform Ross reversal or David reimplantation does not have to be made before the valve has been inspected and the condition of the autograft and anulus is fully known. Whenever in doubt, Ross

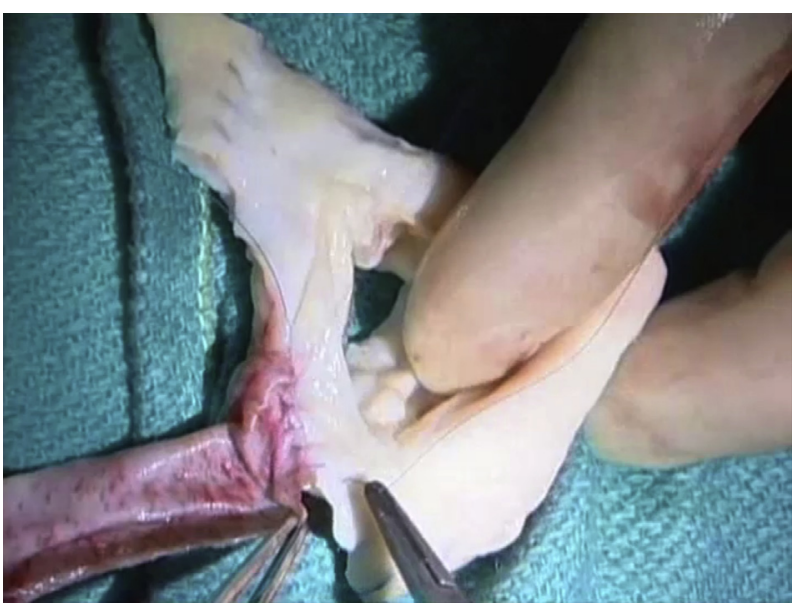

VIDEO 1. Technique of Ross reversal. Video available at: http://www. jtcvsonline.org/article/S0022-5223(17)32386-3/fulltext. reversal rather than David reimplantation has been our choice.

Although the operation is complex, patients have been less complex and the operations well tolerated, as evidenced by smooth postoperative courses and short postoperative hospital stays. This serves to remind us that the risk of any operation is decided more by complexity of the patient than complexity of the operation. ${ }^{20}$

\section{Solutions for Autograft Failure}

Ross reversal addresses both pulmonary autograft dilatation and secondary regurgitation in addition to possible long-term implications of pulmonary allograft (or other right-sided conduit) failure. Discarding an autograft is an important decision for patient and surgeon, and as experience with aortic valve repair and valve-sparing procedures has expanded, pressure on the surgeon to rescue the autograft has increased.

Preserving the autograft in the aortic position is the ideal solution for patients with moderate autograft dilatation, central regurgitation, symmetric cusps, and a wellfunctioning pulmonary allograft. ${ }^{1,18,19,21-23}$ A valvesparing operation to preserve the autograft in the aortic position is not always feasible in patients with valve degeneration, which is a common pathologic finding regardless of the technique used for the Ross procedure. ${ }^{1,6,10,15,23-26}$ 
TABLE 4. In-hospital complications after Ross reversal

\begin{tabular}{lc}
\hline \multicolumn{1}{c}{ Complications } & No. \\
\hline In-hospital death & 0 \\
\hline Return to OR for bleeding/chest washout & 2 \\
\hline Intraoperative adverse events & $1^{*}$ \\
\hline Stroke & 0 \\
\hline Renal insufficiency & $1^{*}$ \\
\hline New renal failure requiring dialysis & $1^{*}$ \\
\hline Prolonged ventilation $(>24$ h) & $1^{*}$ \\
Atrial fibrillation & 5 \\
\hline Myocardial infarction & 0 \\
\hline New heart block & 0 \\
\hline Sternal wound infection & 0 \\
\hline Length of stay & \\
\hline Intensive care unit, h & $21 / 27 / 70^{\dagger}$ \\
\hline Postoperative, d & $5.1 / 7.2 / 9.4 \dagger$ \\
\hline
\end{tabular}

$O R$, Operating room. *All these complications occurred in the same patient (patient \#29 in Table 2). $\dagger 15$ th/50th (median)/85th percentiles.

Often, neither the autograft root nor the cusps are symmetrical, and tissue surrounding the autograft is asymmetrically distributed. Nonetheless, many groups have reported successful David reimplantation for autograft dysfunction. . $^{3,21-23}$

In multiple series, however, many autografts have been discarded, and durability of aortic valve-sparing operations after the Ross procedure remains unknown. ${ }^{1,3,22,23}$ Weimar and colleagues ${ }^{3}$ reported 47 autograft-related reoperations in 44 patients, $22(47 \%)$ performed as a valve-sparing procedure. Luciani and colleagues ${ }^{23}$ reported 27 patients undergoing autograft-related reoperations, for root pathology in 17 and isolated valve pathology in 10. Valve repair/ sparing was performed in $17(63 \%)$, and on follow-up, 6 $(35 \%)$ had required valve repair or replacement at $4.2 \pm 2.9$ years. Liebrich and colleagues ${ }^{22}$ reported 49 autograft-related reoperations between 2005 and 2013, performing a David procedure in 18 of 35 patients $(52 \%)$. In the European multicenter study of 87 valve-sparing reoperations for autograft failure, 1 patient had intraoperative failure and another 15 required autograft valve reoperation during follow-up, for a freedom from reintervention of $76 \%$ at 8 years, a greater failure rate than after a David procedure for any other indication. ${ }^{25}$ Of the 63 patients alive without reintervention after valve-sparing operations, only $41 \%$ were free of aortic valve regurgitation, $16 \%$ had $\geq 2+$ regurgitation, and several experienced cardiacrelated complications.

We are performing large numbers of David reimplantation procedures, 640 to date, and are very comfortable with that procedure for other root pathologies. ${ }^{27}$ However, in patients with failed autografts, we are not comfortable with asymmetry of the cusps, autograft root, and anulus, particularly in the presence of old felt and calcification. After the autograft has been removed, we have been able to debride anulus support material, felt, and calcium. In fact, David himself performed only 1 autograft valve-sparing reimplantation and 3 repairs in 15 autograft-related reoperations in his series of 212 Ross operation patients requiring a reoperation, ${ }^{1,15}$ whereas 11 had valve replacement. He attributed this to abnormal autograft cusps, precluding an aortic valve-sparing procedure. He suggests that it may be unwise to repair the cusps to save the autograft if the cusps are abnormal. Should an autograft valve-sparing operation fail, Ross reversal is probably not possible. $^{1,18,19,23}$

When we previously reported our experience with 60 reoperations after the Ross procedure in adults, ${ }^{19}$ there were no intraoperative adverse events or postoperative deaths, but most failed autografts were discarded and replaced. Toward the end of that series, after introduction of Ross reversal, only 2 autografts were lost during the last 13 reoperations, both of which were potentially salvageable. This trend continued in the current study, in which we were able to rescue the autograft in 35 of the last 39 autograftrelated reoperations, most by Ross reversal and others by valve repair or David reimplantation. Of the 4 lost autografts, 2 (1 attempted repair and 1 attempted David procedure) were potentially good for reversal, whereas the quality of 1 was deemed too poor for rescue, and 1 patient had subcoronary autograft implantation. One potential downside to renewed interest in the original subcoronary autograft implantation technique ${ }^{12,28,29}$ is that these patients may be unsuitable for a Ross reversal in case of autograft failure. With more exposure to failed subcoronary autograft implants, it may be possible that some of these can be explanted and reused if not repairable.

\section{Pulmonary Allograft Failure}

Fate of the pulmonary allograft varies among reports, depending on how dysfunction is defined, and freedom from reoperation does not mean that the pulmonary allograft is perfect. ${ }^{1,12,15,17}$ David's group ${ }^{1}$ reported that almost one half of 212 patients undergoing a Ross operation developed echocardiographic evidence of allograft dysfunction by 20 years. Although freedom from pulmonary allograft reintervention was high $(93 \%)$ at 20 years, many patients are being followed to determine the timing of reintervention. In the German-Dutch Ross registry, freedom from allograft reoperation in adults was $79 \%$ at 12 years. ${ }^{12}$ Pardo González and colleagues ${ }^{30}$ reported allograft stenosis and reintervention 10 years after the Ross procedure of $29 \%$ and $10 \%$, respectively. As evident from David's paper and others, pulmonary allograft dysfunction typically precedes reintervention by many years, and freedom from reintervention does not reflect the true burden of allograft dysfunction. Untreated allograft dysfunction is common 
in the Ross population. Kalfa and colleagues ${ }^{31}$ reported allograft explant in 5\% (explant or intervention in 6\%) and freedom from allograft dysfunction and allograft failure at 10 years of $55 \%$ and $84 \%$, respectively, in 107 patients followed for $5.7 \pm 0.4$ years after a Ross procedure. In our series, the median interval between the original Ross procedure and Ross reversal was 12 years (range 519 years), from an allograft standpoint relatively early.

In addition to reoperation, patients who require reintervention for pulmonary allograft dysfunction now have the option of transcatheter pulmonary valve replacement (TPVR). However, both surgical and transcatheter options carry their own risks. Although percutaneous interventions are possible for pulmonary allograft failure, the calcified allograft is not an ideal platform for these valves, and complications and long-term outcomes are yet to be determined.

TPVR carries an important risk of infective endocarditis and need for additional reinterventions. Gillespie and colleagues $^{32}$ reported 56 such replacements in patients with a previous Ross procedure. Twelve patients required 14 subsequent transcatheter $(n=8)$ or surgical $(n=6)$ pulmonary valve reinterventions. Freedom from TPVR explant was $89 \pm 5 \%$ at 4 years. TPVR endocarditis is a second concern-10.7\% in the study by Gillespie and colleagues-and has also been reported by others. ${ }^{32,33}$ Alassas and colleagues ${ }^{34}$ recently reported on 88 patients undergoing either TPVR $(n=47)$ or surgical $(n=41)$ pulmonary valve interventions after a previous Ross procedure. They found a $13 \%$ occurrence of endocarditis in the TPVR group and no endocarditis in the surgical group. At 5-year follow-up, freedom from pulmonary valve dysfunction (moderate or greater stenosis and/or regurgitation) was $65 \pm 8 \%$ in the TPVR group and only $33 \pm 8 \%$ in the surgical group. TPVR was associated with a greater risk of major adverse cardiac events (composite of death, reintervention, and pulmonary valve endocarditis) compared with surgical pulmonary valve replacement.

Six of our patients had pulmonary valve dysfunction present immediately after Ross reversal, but to date this has been well tolerated, has remained stable, and no patient has required additional intervention.

\section{Clinical Implications}

Reoperations are painful and require the same recuperative time whether they are for aortic or pulmonary valve issues. The possibility of pulmonary autograft rescue by Ross reversal has been an important aspect attracting several of these patients, nationally and internationally, to us. Patients who have undergone a Ross procedure have envisioned a lifelong solution to their aortic valve problem with a valve of their own and are therefore particularly disappointed when they require another operation and face possible loss of a second valve. They are reassured by the possibility of autograft rescue.
For any patient requiring reoperation for autograft or allograft dysfunction, all options should be considered. In our experience, two thirds of reoperations after a Ross procedure have been primarily for autograft causes-dilatation, regurgitation, or both-and one third for pulmonary allograft-related causes. ${ }^{19}$ Often the issues are multiple: The autograft is dilated and regurgitant, the pulmonary allograft is stenotic and regurgitant, and sometimes these issues are present simultaneously, but only one is bad enough to indicate reintervention. The long-term behavior of neither the autograft nor the pulmonary allograft is predictable at any point in time, and future issues requiring intervention are possible and even probable. Other factors to consider are left and right ventricular function, pulmonary pressure, and tricuspid valve function, all of which can affect operative risk and long-term outcomes.

If the patient wants a final operation and accepts a mechanical valve in the aortic position, Ross reversal seems to be the most likely operation to accomplish that goal. Yet as evident in our series, many patients do not want to consider warfarin and choose tissue valves in the aortic position. Nowadays patients are also influenced by the availability of transcatheter aortic valve replacement and count on a Bentall procedure with a bioprosthetic valve to be a platform for future transcatheter aortic valve replacement. Allograft aortic root replacement was performed primarily early during the study period as an alternative to a biologic valve to avoid warfarin; it has not been performed in any of the last 21 Ross reversals. Ross reversal for a failed allograft with a well-functioning autograft in the aortic position has not been performed.

\section{Limitations}

Our series of Ross reversals is small, and all cases were performed by a single surgeon who has extensive experience with the Ross and aortic valve-sparing operations, as well as allograft reoperations. Performing these operations requires experience with complex aortic root surgery. We may also have been more inclined to perform the Ross reversal as experience, reproducibility, and reliability increased our confidence in the operation. Although most of our patients had acceptable pulmonary valve function, longer follow-up is necessary to confirm its long-term superiority over the original allograft in the pulmonic position.

\section{CONCLUSIONS}

Ross reversal is a reproducible and reliable operation that can be performed with low morbidity and good pulmonary valve function in the majority of patients. The prospect of reversibility of the Ross procedure, with good and durable function of the pulmonary autograft returned to its pulmonary position, provides reassurance to patients considering the Ross operation and weakens the argument that the procedure transforms a 1-valve disease into a 2 -valve disease. 
Our mid-term results, with no reoperations, suggest that we should continue to perform this operation and continue to follow patients to confirm the longevity of the rescued autograft valves.

\section{Webcast}

You can watch a Webcast of this AATS meeting presentation by going to: https://aats.blob.core.windows.net/ media/17AM/2017-05-03/RM306/05-03-17_Room306 0838_Hussain.mp4.

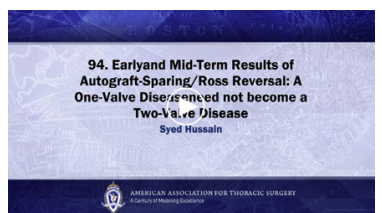

\section{Conflict of Interest Statement}

Authors have nothing to disclose with regard to commercial support.

\section{References}

1. David TE, David C, Woo A, Manlhiot C. The Ross procedure: outcomes at 20 years. J Thorac Cardiovasc Surg. 2014; 147:85-93.

2. Reece TB, Welke KF, O'Brien S, Grau-Sepulveda MV, Grover FL, Gammie JS. Rethinking the Ross procedure in adults. Ann Thorac Surg. 2014;97:175-81.

3. Weimar T, Charitos EI, Liebrich M, Roser D, Tzanavaros I, Doll N, et al. Quo vadis pulmonary autograft-the Ross procedure in its second decade: a singlecenter experience in 645 patients. Ann Thorac Surg. 2014;97:167-74.

4. da Costa FD, Takkenberg JJ, Fornazari D, Balbi Filho EM, Colatusso C, Mokhles MM, et al. Long-term results of the Ross operation: an 18-year single institutional experience. Eur J Cardiothorac Surg. 2014;46:415-22.

5. Mokhles MM, Rizopoulos D, Andrinopoulou ER, Bekkers JA, RoosHesselink JW, Lesaffre E, et al. Autograft and pulmonary allograft performance in the second post-operative decade after the Ross procedure: insights from the Rotterdam Prospective Cohort Study. Eur Heart J. 2012;33:2213-24.

6. David TE, Woo A, Armstrong S, Maganti M. When is the Ross operation a good option to treat aortic valve disease? J Thorac Cardiovasc Surg. 2010;139:68-75.

7. Bohm JO, Hemmer W, Rein JG, Horke A, Roser D, Blumenstock G, et al. A single-institution experience with the Ross operation over 11 years. Ann Thorac Surg. 2009;87:514-20.

8. Kouchoukos NT, Masetti P, Nickerson NJ, Castner CF, Shannon WD, DavilaRoman VG. The Ross procedure: long-term clinical and echocardiographic follow-up. Ann Thorac Surg. 2004;78:773-81.

9. Takkenberg JJ, Klieverik LM, Schoof PH, van Suylen RJ, van Herwerden LA, Zondervan PE, et al. The Ross procedure: a systematic review and meta-analysis. Circulation. 2009;119:222-8

10. Elkins RC, Thompson DM, Lane MM, Elkins CC, Peyton MD. Ross operation: 16-year experience. J Thorac Cardiovasc Surg. 2008;136:623-30.

11. David TE, Omran A, Ivanov J, Armstrong S, de Sa MP, Sonnenberg B, et al. Dilation of the pulmonary autograft after the Ross procedure. J Thorac Cardiovasc Surg. 2000;119:210-20.

12. Charitos EI, Takkenberg JJ, Hanke T, Gorski A, Botha C, Franke U, et al. Reoperations on the pulmonary autograft and pulmonary homograft after the Ross procedure: an update on the German Dutch Ross Registry. J Thorac Cardiovasc Surg. 2012;144:813-23

13. Juthier F, Vincentelli A, Pincon C, Banfi C, Ennezat PV, Marechaux S, et al. Reoperation after the Ross procedure: incidence, management, and survival. Ann Thorac Surg. 2012:93:598-605.
14. Stulak JM, Burkhart HM, Sundt TM III, Connolly HM, Suri RM, Schaff HV, et al Spectrum and outcome of reoperations after the Ross procedure. Circulation 2010;122:1153-8

15. David TE. Reoperations after the Ross procedure. Circulation. 2010;122:1139-40.

16. Luciani GB, Favaro A, Casali G, Santini F, Mazzucco A. Reoperations for aortic aneurysm after the Ross procedure. J Heart Valve Dis. 2005;14:766-73.

17. Brown JW, Ruzmetov M, Rodefeld MD, Turrentine MW. Right ventricular outflow tract reconstruction in Ross patients: does the homograft fare better? Ann Thorac Surg. 2008;86:1607-12.

18. Flynn M, Little SG, Blackstone EH, Pettersson GB. Reversing the Ross operation: a new reoperation option for autograft failure. J Thorac Cardiovasc Surg 2007; $133: 1645-7$

19. Pettersson GB, Subramanian S, Flynn M, Nowicki ER, Batizy LH, Svensson LG, et al. Reoperations after the Ross procedure in adults: towards autograft-sparing/ Ross reversal. J Heart Valve Dis. 2011:20:425-32.

20. Pettersson GB, Martino D, Blackstone EH, Nowicki ER, Houghtaling PL, Sabik JF III, et al. Advising complex patients who require complex heart operations. J Thorac Cardiovasc Surg. 2013;145:1159-69.e3.

21. de Kerchove L, Boodhwani M, Etienne PY, Poncelet A, Glineur D, Noirhomme P, et al. Preservation of the pulmonary autograft after failure of the Ross procedure Eur J Cardiothorac Surg. 2010;38:326-32.

22. Liebrich M, Weimar T, Tzanavaros I, Roser D, Doll KN, Hemmer WB. The David procedure for salvage of a failing autograft after the Ross operation. Ann Thorac Surg. 2014;98:2046-52.

23. Luciani GB, Lucchese G, De Rita F, Puppini G, Faggian G, Mazzucco A. Reparative surgery of the pulmonary autograft: experience with Ross reoperations. Eur J Cardiothorac Surg. 2012;41:1309-15.

24. de Sa M, Moshkovitz Y, Butany J, David TE. Histologic abnormalities of the ascending aorta and pulmonary trunk in patients with bicuspid aortic valve disease: clinical relevance to the ross procedure. J Thorac Cardiovasc Surg. 1999; 118:588-94

25. Mookhoek A, de Heer E, Bogers AJ, Takkenberg JJ, Schoof PH. Pulmonary autograft valve explants show typical degeneration. J Thorac Cardiovasc Surg. 2010; 139:1416-9.

26. de Kerchove L, Rubay J, Pasquet A, Poncelet A, Ovaert C, Pirotte M, et al. Ross operation in the adult: long-term outcomes after root replacement and inclusion techniques. Ann Thorac Surg. 2009;87:95-102.

27. Svensson LG, Pillai ST, Rajeswaran J, Desai MY, Griffin B, Grimm R, et al. Long-term survival, valve durability, and reoperation for 4 aortic root procedure combined with ascending aorta replacement. J Thorac Cardiovasc Surg. 2016; $151: 764-71$ e $1-4$

28. Charitos EI, Stierle U, Hanke T, Schmidtke C, Sievers HH, Richardt D. Long term results of 203 young and middle-aged patients with more than 10 years of follow-up after the original subcoronary Ross operation. Ann Thorac Surg. 2012:93:495-502.

29. Sievers HH, Hanke T, Stierle U, Bechtel MF, Graf B, Robinson DR, et al. A critical reappraisal of the Ross operation: renaissance of the subcoronary implantation technique? Circulation. 2006;114:1504-11.

30. Pardo González L, Ruiz Ortiz M, Delgado M, Mesa D, Villalba R, Rodriguez S, et al Pulmonary homograft stenosis in the Ross procedure: incidence, clinical impact and predictors in long-term follow-up. Arch Cardiovasc Dis. 2017;110:214-22.

31. Kalfa D, Feier H, Loundou A, Fraisse A, Mace L, Metras D, et al. Cryopreserved homograft in the Ross procedure: outcomes and prognostic factors. J Heart Valve Dis. 2011;20:571-81.

32. Gillespie MJ, McElhinney DB, Kreutzer J, Hellenbrand WE, El-Said H, Ewert P et al. Transcatheter pulmonary valve replacement for right ventricular outflow tract conduit dysfunction after the Ross procedure. Ann Thorac Surg. 2015 100:996-1002; discussion 3 .

33. Holzer RJ, Hijazi ZM. Transcatheter pulmonary valve replacement: state of the art. Catheter Cardiovasc Interv. 2016:87:117-28.

34. Alassas K, Hijji T, Husain A, Eldali A, Dahdouh Z, Pergola V, et al. Transcatheter or surgical intervention for the failed pulmonary valve homograft in the Ross population? [Abstract]. Presented at: the 97th Annual Meeting of The American Association for Thoracic Surgery; April 29-May 3, 2017; Boston, Mass.

Key Words: Ross procedure/operation, reoperation, autograft failure, Ross reversal, autograft rescue, aortic valve replacement 


\section{Discussion}

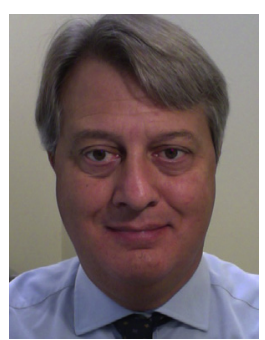

Dr G. Luciani (Verona, Italy). I appreciate the privilege of discussing this paper from Dr Hussain and colleagues from the Cleveland Clinic.

Hussain and colleagues report on a clever technique they had using 30 Ross patients undergoing left heart reoperation, which allows to essentially recycle a dysfunctional autograft valve by using it to replace the pulmonary allograft or homograft. The early and midterm outcomes are certainly encouraging. Although the goal to turn the Ross procedure into a one-valve disease may be very laudable, my impression is that further follow-up needs to be accrued before postulating that no reoperations will be needed on the right heart.

Nonetheless, the authors need to be congratulated for carrying out such a complex autograft root reoperation without incurring significant hospital mortality or morbidity, and previous studies even from the Mayo Clinic or other institutions with a limited experience with the Ross procedure have shown significant morbidity and mortality with reoperations. These results speak for the long-standing acquaintance with complex aortic root surgery by the surgeons at the Cleveland Clinic. So, my congratulations.

I have 3 questions. In our institutional experience, as well as in the experience of a recent multicentric European study focusing on salvage of the autograft root and valve in $6 \mathrm{Eu}-$ ropean units, the need to reoperate on the right heart is actually very low, around $16 \%$. Now, I am referring to 6 cardiac units that over a 16-year time span performed a total of 197 reoperations of a total of 1783 Ross procedures. Therefore, the rate of reoperation was around $11 \%$ and of these nearly one half, 87 to be precise, were root salvage operations. During an 8-year follow-up an $85 \%$ freedom from subsequent reoperations either on the left or the right heart was observed. Interestingly, in that series the incidence of right heart reoperation was extremely low.

So my first question is, what would the authors recommend in such cases, about $80 \%$ in your series, where the pulmonary homograft valve function is not so severely affected, so that replacement would not be formally indicated? Would they still advise intervening on the right heart in those patients?

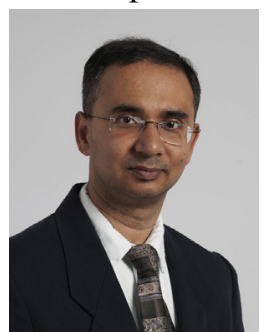

Dr Hussain (Cleveland, ohio). First of all, thank you very much for your excellent comments. The main question is whether we should replace the pulmonary allograft if we are reoperating primarily for allograft dysfunction.

In most of the studies, as you have mentioned, and even in Dr David's recent series of more than 200 patients who underwent a
Ross reversal and were followed up more than 20 years, although freedom from reintervention on the right ventricular outflow tract (RVOT) was $93 \%$ at 20 years, more than $50 \%$ of those patients had developed echocardiographic evidence of pulmonary allograft dysfunction, which had not yet required reoperation at that stage. So what we think is that once patients are out 15 to 20 years, they start to develop more severe pulmonary valve issues and may require a subsequent reoperation over the next few years.

All the reoperations in our series were driven by autograft failure, and these failures occurred at a median interval between the original Ross procedure and Ross reversal of 12 years. From an allograft standpoint this is relatively early, although only 4 of the 30 patients in our series had normal pulmonary allograft valve function by echocardiography at the time of reoperation. Few allografts are perfect even if dysfunction is mild and would not trigger a reoperation by themselves. We have not considered performing a reverse Ross for failed allografts in the pulmonary position with well-functioning autografts in the aortic position. We certainly believe that the live, rescued, and repositioned autograft will perform equally well or better than the original allograft, even if it is still relatively good after 10 to 15 years. We think that in those patients, if we are able to put the native valve back into the pulmonary position, they should work better, because, first of all, they have been exposed to greater pressure for a while. So although they are not a perfect valve for the aortic position, they should do much better because they are native valves. Seven of our 30 patients had no real indication for reoperation on the allograft per se, but we did replace them because we think they would subsequently require interventions, and obviously our main aim was to make sure that our results are good to be able to justify that.

We are working on our long-term results, so obviously at this stage we cannot say that this is the right operation for everybody, but this is one of the operations I think might turn out to be very helpful, based on our initial results.

Dr Luciani. My second question. Basically, 2 scenarios lead to a left heart reoperation in Ross patients. The most common is aneurysmal autograft dilation, and in those cases whether you have valve regurgitation or not, a root operation is indicated, such as the one you have shown. However, nearly $20 \%$ of our Ross reinterventions both in our institution and in the European multicenter series were in patients with isolated aortic autograft valve regurgitation.

Now, the approach you are presenting today there entails a lot of complex reoperative root surgery. I am sure for the average cardiac surgeon it would be significantly more challenging to reproduce this operation rather than simply replacing the autograft valve with an aortic prosthesis. Would you still advise your procedure in patients who present with isolated autograft valve dysfunction, thus with a substantially normal autograft root? 
Dr Hussain. As I mentioned earlier, our first instinct is not the reverse Ross operation. We have not considered performing a reverse Ross for failed allografts in the pulmonary position with well-functioning autografts in the aortic position. When we are going for these reoperations, for isolated aortic valve root issues for example, we still first try to repair the autograft, and then if we can't repair it, our next step is to see if we can do a David reimplantation. Because the initial step for either a reverse Ross or a David is exactly the same, you still have to work on the root.

Dr Luciani. I understand, but if the patient presents only with isolated valve dysfunction, what would you do? The root is essentially normal; therefore, it has no indication to be replaced. Would you still go through with a root the operation or not?

Dr Hussain. Our first attempt will be to try to repair the valve. If we cannot repair it or we think we need to replace the valve, then in that case, now with the increasing experience with Ross reversal, we will try to do this operation to salvage the autograft.

We have Dr Pettersson present here. He is the best person to tell us his thoughts on this operation.

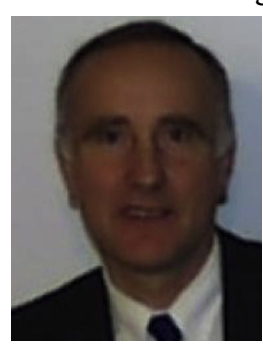

Dr G. Pettersson (Cleveland, Ohio). I will just make a small comment. One of the consequences of doing Ross reversals is that you get much more comfortable with dissecting out the root. Our ability to do the David procedure has actually improved, and we have become more comfortable with evaluating the valve. As the pressure not to move a valve over to the pulmonic position increases, we are going to do more and better valve-sparing operations as a consequence of the experience with Ross reversal.

Dr Luciani. Thank you. The last question. As you know, there are several alternative options to the treatment you are presenting today. Among these is a transcatheter valve approach replacement of dysfunctional pulmonary homografts, although the long-term outcomes have not been published in large series yet. This strategy has the advantage of being less invasive than surgery, and it can be easily planned independently from a left heart reoperation.

Therefore, what do you perceive may be the role for the procedure presented today, in light of the fact that there are suitable, less invasive alternatives? Thank you.

Dr Hussain. Thank you very much. That's a very good question, obviously. There are definitely options for the transcatheter technique, but in very calcified homografts, which obviously might occur based on our own experience on the other RVOT conduits, it may not always work out exactly as we think. So our main aim and, again, the goal was, if we can place the native valve back in position absolutely safely with no cost to pay for it, more or less, then we think that is the right approach, because nothing can beat the native valve itself in its own position. And as we have seen in the 10 years of follow-up we have, we haven't had any indication for any intervention in any of these patients. And also understand that all these valves we initially excised are kind of dilated valves; they do not look optimal, but in the RVOT in the pulmonary position they function very well.

So we still think that until we have a much clearer answer on how these transcatheter valves function in the long run, this may be a very good alternative. Again, we are still working on more details, but these are the preliminary results, which I think are very encouraging.

Dr Luciani. In conclusion, I enjoyed reading your paper in advance and discussing this interesting technique. We will all be looking forward to your long-term results.

My personal impression is that the strongest argument in favor of your approach today is cost containment. Thank you again. 